\title{
Industrial Exports and Economic Development in Iran
}

\author{
${ }^{1}$ Safdari Mehdi, ${ }^{2}$ Motiee Reza \\ 1University of Qom, Iran \\ 2Department of Economics, Babol Branch, Islamic Azad University, Babol, Iran \\ *rm.search2011@gmail.com
}

\begin{abstract}
This research seeks to determine the effect of human capital and physical and non-oil exports of industrial sector, the real Gross Domestic Product (GDP) in the country during 1959 to 2007. The purpose of this study is to determine the relationship between Industrial exports and economic growth in Iran. The theoretical framework was designed based on this assumption that the total GDP in the economy is divided into two sections, production for inside and production for export. The data were collected from 1959 to 2007 and was analyzed using Ordinary Least Squares (OLS) model. The result of the analyses shows that there is significant relationship between Industrial exports and economic growth. Together, the independent variables explained $93 \%$ of the variance in the dependent variables. In relation to that, it is concluded that explanatory power is high for the equation that shows that one percent change in Industrial exports rate lead to $44 \%$ in economic growth. Therefore, an Industrial export is regarded as an important factor in Iran's economic growth.
\end{abstract}

Keywords: Gross Domestic Product (GDP), Augmented Dickey-Fuller (ADF) test, Ordinary Least Squares (OLS) model

\section{Introduction}

Industry has a special place in the field of technical innovations, research and development to achieve economic development of any country. For example, EU member countries in Europe more than fifty percent of the financial resources needed for $\mathrm{R} \& \mathrm{D}$ activities are provided by the industrial sector. Economic development process in the past 30 years, has been demonstrated many ups and downs, and positive and negative shocks in Iran. Competitive conditions in the field of quality and price of goods in international economics, has led to economic decision makers in the country to have an acceptable understanding of the necessity of use of non-oil exports. Thus many industrial goods are produced within, which was previously produced from foreign markets and was imported to the country. Therefore, the prevention of importation of foreign goods, protection of domestic markets as well as policies is followed. Change in economic orientation and tendency towards entering the export markets requires that the industrial sector, to adapt him self to circumstances and competitive criteria. Some of these criteria include: International standards, applying advanced technology and commitment to controlling quality of goods produced and improve methods of packing goods. However, access to international markets should be done depends on the steps above and revised policies and strategies on industrial countries to industrialized countries and less developed markets be opened to the Islamic Republic of Iran on building products.

If be review the status of non-oil exports (industrial, services and etc) to two periods before and after the revolution, it can be say that in the years (1978-1963), foreign exchange earnings from export of oil, the possibility of importing the necessary provided for increasing the country's consumption and industrial development. Since the industrial sector and export, revenue is derived from one of the most important sources of investment financing in developing countries, so in this paper provides econometric models and techniques and the results can be paid to identifying the parameters essential for export development and economic planning and long term. Also important goal in this paper is that implementation can be evaluated with applying new methods and econometric techniques the role of export of industrial countries in the process of economic growth more accurately, to economic planners and policy makers in order according to country The estimated results of models used in this study to address the policy and planning and long term.

Export in Iran's economy: Slow economic growth along with demographic developments, the country's per capita income is kept extremely low in comparison with other developing countries, industrial. According to World Development indicators 2002, per capita income have reported in terms of dollars 
based on exchange rates and the method of PPP, respectively equal to $\$ 1680$ and 5910 . Similar numerals for South Korea equal to 8910 and \$17300, and Malaysia are equivalent to U.S. \$3380 and 8330. In Iran's economy, investment developments in the period 1961-2001 are also indicated severe fluctuations, especially in the two decades 1971 and 1981. Average annual growth rate of investment in decades of 1961 is equivalent to 12.4 percent, 1972-1976 period due to the occurrence of the first oil shock is equivalent to 24.7 percent, In the period 1977-1988 (the years of war and revolution) is equivalent to -7 percent, and in the years 2001 to 1989 period is equivalent to 7.9 percent. In 1991 decade, the share of investment in GDP has been relatively stable but slow process after decades of severe fluctuations in 1971 and 1981. This contribution is based on national accounts numbers of investment and production cost in 1982 and in 2001 the equivalent of 15.1 percent.

Review value-added process in industrial sector in Iran: In this section, we review processing economic sectors value added in Iran. The following table shows the average annual of value-added and growth it in economic sectors in the period of 1961-2006.

Table 1: Average annual value Added and growth value-added economic sectors

\begin{tabular}{ccccccc}
\hline \multirow{2}{*}{ Period } & \multicolumn{2}{c}{$\begin{array}{c}\text { Average annual growth of value added } \\
\text { (percent) }\end{array}$} & \multicolumn{3}{c}{$\begin{array}{c}\text { Average annual value added (billion } \\
\text { Rials }{ }^{1} \text { ) }\end{array}$} \\
\cline { 2 - 7 } & Services & Agriculture & $\begin{array}{c}\text { Industry } \\
\text { and mining }\end{array}$ & Services & Agriculture & $\begin{array}{c}\text { Industry } \\
\text { and mining }\end{array}$ \\
\cline { 2 - 7 } & 8.79 & 3.17 & 13.08 & 32298 & 10058.55 & 7724.73 \\
$1961-1972$ & 16.26 & 6.74 & 16.95 & 93012.67 & 15656 & 24234.17 \\
$1973-1977$ & -2.05 & 4.71 & -0.44 & 117373 & 23834 & 30816.82 \\
$1978-1988$ & 6.52 & 6.45 & 10.62 & 118625 & 35205.6 & 41899.2 \\
$1989-1993$ & 6.52 & 5.39 & 151466 & 43849 & 55599.2 \\
$1994-1999$ & 4.16 & 2.25 & 10.23 & 189306.45 & 49625 & 83280.22 \\
$2000-2004$ & 5.69 & 4.01 & 10.48 & 236185.5 & 59761.5 & 116712.5 \\
$2005-2006$ & 6.52 & 6.93 & & & & \\
\hline
\end{tabular}

Source: central bank of Iran

Industry and mining section have involved effective during 1961-1968 in Iran's economic development. In1970 industry prospered in High level by government's support of industry and donations industrial Bank and increasing investment. Hence growth in industry and mining sector reached to 13.8 percent. Value added growth in industry and mining section reached to the 13.5 percent in 1971 and was more than predicted goal in the fourth development plan. With widespread strikes in 1998, industrial and mining activities was decreased too much, therefore economic in Iran was faced with the relative stagnation by the Islamic Revolution and problems such as shortages of imported raw materials in small industries. In despite of these conditions the added value in industry and mining section increased about 5.1 percent. Industry and mining section in first Five-year Development Plan (FYDP) ${ }^{2}$ III executive (2000) situation was relatively stable. Improving government financial, country's balance of current account surplus and monetary policy supplier financing economic development leaded to fixed Price and exchange rate and to fall inflationary expectations and provided the appropriate to support this sector and the value added in this section grew amount of 9.5 percent than 1999 year.

Export process in industrial and mining sector: The most important disorder that occurred in the first Five-year Development Plan (FYDP) was oil shock in 1974 and increasing exchange incomes obtained from exports so that was leaded to the release of uncontrolled boundaries for imports and much damage had exposed industries that compete with similar foreign products. In during 1979-1988 with Islamic revolution, export in industrial and mining sector has had several fluctuations due to: investment impairment, get out a number of capitalists and revenue operators, macro debt companies, factories to the banking system and imposed war and economic boycott. During 1979-1982 export in industrial and mining sector was a decreasing trend but from 1982 onwards exchange requirement and decreasing incomes result of crude oil exports by export incentive policies. During this period, export from 173.9 million dollars in the beginning period has reached to 265.5 million dollars in the end. In during 19891993 (end of war and beginning first-year development plan) export value has climbed in industry and

${ }^{1}$ IRR is monetary unit in Iran. Based on ISO-4217 standard Iran's Rial is shown with the symbol IRR In global trading. 2 Iran's FYDP was initiated since the end of Iran-Iraq war in 1988. High rates of economic growth for a decade is a strategic approach as well as an outstanding issue in the 4th five-year development plan of Iran (March 2005-2010). 
mining sector due to fluctuations in the amount. In second-year development plan became more attention to export in industrial and mining sector and has climbed according to developments in 1994-1995, exchange rate fluctuations and uncontrolled price increases. In third-year development plan trade liberalization and realization of export mutants was the desired goals. In this period export value in industrial and mining sector from 2299.5 million dollars in 2000 reached to 4955.6 million dollars in 2004.

Table 2: The average combined share of exports in economic sectors (percent)

\begin{tabular}{ccccc}
\hline Period time & Oil & Agriculture & Industry and mining & Services \\
\hline $1961-1971$ & 84 & 7 & 2 & 7 \\
$1972-1977$ & 85 & 3 & 1 & 11 \\
$1978-1988$ & 88 & 4 & 1 & 7 \\
$1989-1993$ & 83 & 9 & 3 & 5 \\
$1994-1999$ & 76 & 9 & 8 & 7 \\
$2000-2004$ & 73 & 5 & 9 & 13 \\
$2005-2006$ & 74 & 4 & 11 & 10 \\
\hline
\end{tabular}

Source: Central Bank of Iran

\section{Literature Review}

Economic growth is one of the major topics of modern economics. Smith (1776) and the classical school of followers raised considerable discussions and theories about economic growth. Then, especially after the First World War, according to economists attracted long-term economic growth, so that they believed economic growth a function of domestic resources, population growth rates, savings rates and ways to organize and manage economic technology and the effects on capital accumulation and increased production and exports. On the other hand has been one of the major empirical studies regarding the effect on total foreign trade export in 1978 by Ballassa. This study shows positive effect on economic growth, export growth. A policy related to exports compared with cause-oriented policies within is more economic growth. Feder (1982) conducted that 31 developing countries outlined the cause's exports to increase economic growth through the side effects and by increasing productivity. Also Helpmen \& Grossman (1991) are expressed in their studies according to the above production function, the longterm growth rate depends on the different parts of the production rate of human capital in empirical studies define human capital in the middle educated employees, the whole country as an indicator of human capital.

In field studies by researchers like Komeyjani \& Memarnejad (2004) documented the importance of quality human resources on economic growth in Iran's workforce and human capital, physical capital is positive and significant impact on economic growth in Iran. In examining and reviewing records can be seen that Chow (1987) investigates relationship between export growth and industrial growth in eight countries with newly industrialized Sims test. Of empirically Wood (1997) showed countries that have natural resources, if the workforce skills be high, they can be exporter of industrial products. In the other hand if the skills be low, exports will focused on primary goods in those countries. Raymo (1995) examined the role of human capital on economic growth in Japan during the period 1970-1991 and concluded that to obtain share it in Gross Domestic Product (GDP). Based on his opinion, production function in general form is following: $Y=f(K, L, H K)$ where $Y$ is Gross Domestic Product (GDP), $L$ is full employment and $K$ is human capital. Here is the production function as cobb douglas function and is assumed that efficient to scale is fixed and is defined in the following: $Y=A K^{\alpha} L^{\beta} H K^{\gamma} e^{\varepsilon}$, then obtained to an equation be estimated by logarithm of Cobb-Douglas Production Function in the following: $\operatorname{LnY}=\operatorname{Ln} A+$ $\alpha L n K+\beta L n L+\gamma L n H K+\varepsilon$, and concluded that expenditure spent on Training and average years of education for workforce have a positive and significant impact on the economic growth in Japan as two indicators of human capital.

\section{Methodology}

In this section we want to estimate the process variables used in the model then introduce the Feder model in the study and then stationary and non stationary variables will be examined by the ADF test. Model used in this study is Feder model. In this model, the total production in the economy is segregated 
into two parts production for inside (N) and production for exports (X) and production each one of two parts is a function of factors allocated capital and labor. In addition, production the non-export section depends on volume of export:

$$
\begin{aligned}
& N=F\left(K_{n}, L_{n}, X\right) \\
& X=G\left(K_{X}, L_{X}\right) \\
& Y=N+X
\end{aligned}
$$

Where N: non export sector, $\mathrm{X}$ : export sector, $\left(\mathrm{K}_{\mathrm{n}}, \mathrm{K}_{\mathrm{X}}\right)$ : capital stock in two sector, $(\mathrm{Ln}, \mathrm{Lx})$ : Labor in two sector. We assume that the productivity of production factors is greater in export section and is establish the following equation:

$$
\frac{G_{k}}{F_{k}}=\frac{G_{l}}{F_{l}}=1+\delta
$$

Where $\delta$ is a rate difference production factor in the marginal productivity in two sections. For obtain the growth relationship we make differential from equations (1) and (2) and after doing mathematical equations will be as follows:

$$
\frac{\dot{Y}}{Y}=\alpha \frac{I}{Y}+\beta \frac{\dot{L}}{L}+\theta \frac{\dot{X}}{X}
$$

Where, Y: economic sectors value-added, I: investment in economic sectors, L: employment economic sectors and $\mathrm{X}$ : export in economic sectors

Therefore following is the general form of production function model:

$\operatorname{LGDP}_{\mathrm{t}}=\alpha_{0}+\alpha_{1} \operatorname{LINEX}_{\mathrm{t}}+\alpha_{2} \mathrm{LLA}_{\mathrm{t}}+\alpha_{3} \mathrm{LK}_{\mathrm{t}}+\mathrm{DU} 57$

Where:

LGDP: $\log$ GDP per capita in 1997 constant prices According to million Rials

LINEX: $\log$ industrial export based on 1997 constant prices According to Rials

$L_{L A}:$ logarithm of average years of education employees nationwide as an indicator of human capital $\mathrm{LK}_{\mathrm{t}}$ : logarithm of physical capital stock per capita in 1997 constant prices According to million Rials DU57: variable for dummy revolution (for which its value before 1978, and to zero after that is one.) $\alpha_{0}$ : constant

Unit root test by Augmented Dickey - Fuller (ADF): The review stationary or non stationary for time series is one of the major topics in time series analysis and generally when a time series is stationary that during time Mean, variance, covariance and correlation coefficient remain constant. One of the methods for determining stationary is Unit root test by Augmented Dickey - Fuller (ADF), this test is based on following equation:

$$
\Delta Y_{t}=\alpha+\beta t+m Y_{t-1}+\sum_{i=1}^{m} \alpha_{i} \Delta Y_{t-i}+\varepsilon_{t}
$$

Where $\Delta$ is operator difference first order and $\varepsilon_{\mathrm{t}}$ is error pure impaired.

$$
\left\{\begin{array}{l}
H_{0}: m=0 \\
H_{1}=m<0
\end{array}\right.
$$

Zero hypotheses are that time series variable has unit root. In fact, this test is the assumption having unit root (non stationary) or having no unit root (stationary).

Heteroskedasticity and Serial Correlation: One of fundamental acceptability for regression is equality of variance sentences impaired. If variance disturbing sentences not be fixed in different observations, we will be faced to heteroskedasticity problem. Consequences due to heteroskedasticity variance disturbing sentences is that Ordinary Least Square (OLS) estimators are not efficient and estimated variances coefficient slant and also doing heteroskedasticity test and making confidence interval is rejected from the degree of credibility therefore heteroskedasticity test is necessary. Other fundamental acceptability for regression is being non-correlation disturbing sentences in different observations. If fundamental to be violated, we will face to serial correlation problem. Therefore Serial correlation test is necessary.

Unit root test generalized Dickey - Fuller: In estimating regression models as time series first, stationary of time series must be approved and then model should be estimate. Values of statistics reported and compared with critical values indicate that all variables are non-reliable and GD Booth once (the variable component of physical capital differences measured twice), come in a steady state stationary. Based on tests conducted it is zero and there will not reject unit root for all variables and critical at all levels, and all variables in the data model are unstable. But repeated tests show the first 
difference variables and the second difference for the variable physical capital; that all the variables unstable rejected the hypothesis can be reliably measured after subtraction.

Table 3: Result of unit root tests by Augmented Dickey-fuller (ADF)

\begin{tabular}{ccc}
\hline Variable & statistic & Critical value \\
\hline DLGDP & -4.32 & $-3.58[001]$ \\
DLINEX & -5.85 & $-3.58[001]$ \\
DLLA & -6.46 & $-3.58[001]$ \\
DLK & -4.95 & $-3.58[001]$ \\
\hline
\end{tabular}

Of course, in Iran with a major structural change such as revolution, war and oil shocks faced by traditional methods such as unit root tests Dickey - Fuller generalized, loses its efficiency and unit root tests should be used in the present structural failure. More can be said that based on other studies doing unit root tests with structural breaks and considering only one structural break three non stationary variable lead to stationary variables and considering one only structural break, more than half of the non stationary variables will be stationary. Since this research is faced with combination of stationary and non stationary variables, has been selected Ordinary Least Square (OLS) as most appropriate method.

Test results of short and long term: Auto regressive distributed lag model in short-term with distributed delay is estimated as follows:

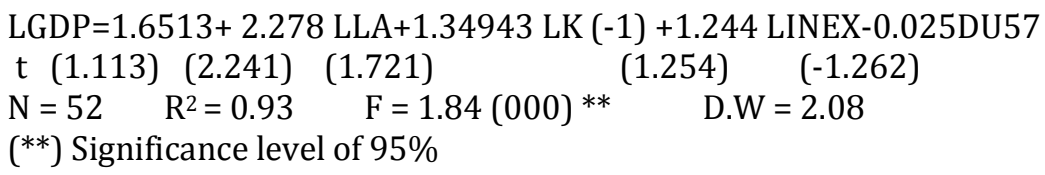

Also can be point to stability and diagnostic Granger causality tests and the results of these tests show that this research is not faced with serial correlation, heteroscedasticity and function form and results are defensible. Long-term Ordinary Least Square (OLS) model is as follows:

$$
\begin{aligned}
& \text { LGDP }=1.35+2.193 \text { LLA +1.646LK+1.116 LINEX-0.559 DU57 } \\
& \text { t (1.849) (1.795) (1.842) (1.779) (-1.879) }
\end{aligned}
$$

\section{Discussion}

First, this research reviewed Stationary and non-stationary variables using Dickey-Fuller (ADF) and more than half of non-stationary variables with considering structural breaks show Stationary process. It found that the most significant structural breaks occurring over the last four decades and which were detected endogenously. As expected, physical capital, human and industrial exports have a positive effect on all the national production; in the country and are consistent with theoretical expectations. And variable for livestock revolution has had a negative effect on national production. Results show that based on the model Ordinary Least Square (OLS) is a long term relationship between the variables given. Also the adjustment speed coefficient is statistically significant that their long-term relationship between variables model confirms again and is in fact indicated a relatively high speed of adjustment. The result are presented from a smaller negative coefficient and indicates that if it move from one period to the next period, the diversion rate of $50 \%$ of national production is corrected by long path template variables.

Human capital coefficient is positive and equal to 2.193 which shows that whit every percent increase in human capital, economic growth will increase by 2.1 percent. The positive and meaningful effect of this variable on Iran's economic could be seen as the result of using technologies in industrial export fields, and also partly as the positive result of research on productivity and production. This result is along with the positive and meaningful role of human capital as asserted in Endogenous economic growth models which are proved to be useful for Iranian economy. Altogether, the results of this study show that average industrial exports in Iran have a meaningful and positive effect on country's economic growth. So it's only sensible to pay serious attention toward the quality and quantity of industrial exports in the country. Government must allocate more budgets to export field in order to help this situation. 


\section{Conclusion and Recommendations}

Experimental results of this study show that macroeconomic variable (non-oil exports in industrial, human capital and physical sector) has an effect on Gross Domestic Product (GDP) directly and considerable. Results show that in countries that have actual production and high economic growth and rising are often to rely on non-oil exports. Thus, results are that in Iran is very dependent on the oil revenues, is a way to raise economic growth to the non-oil industrial exports, and one of the Dutch disease elimination strategies in regard to Iran has been exporting non-oil. Therefore there is a positive relationship between national production, exports and industrial. Results of Long term equilibrium relationship test indicates that there is a positive and significant relationship between non-oil export sector and national industrial production and results of tests are mentioned variables showed that export of industrial and human capital and physical impact on national production and had a positive and direct variable periods livestock revolution has had a negative effect on national production; It is clear that oil exports in this period revenue from the interest was more than non-oil export sector.

Estimation results show that non oil exports are most influential factor on Iran's economic growth continuously and according to volatility in oil market and Iran's oil resources will be missed therefore it is essential to reduce dependence on oil revenues and more attention to developing non-oil exports in Iran's economy. In general can be said that doing any supportive policy lead to decrease in national exportable. It states that developing non-oil exports should be led to national foreign trade policy including remove protectionist policies (such as doing tariff), foreign exchange restrictions and rationing. By this doing, prices will be real in entering, exportable and business goods sector and increasing exports will advantage from guidance to production and consumption resources in the community consequently nonoil exports will rise.

\section{References}

Ballassa, B. (1978). Exports and Economic Growth: Further Evidence. Journal of Development Economics, $5,181-189$.

Chow, P., Y. (1987). Causality between Export and Industrial Development: Empirical Evidence from NICs. Journal of Development Economics 26, 55-63.

Dickey, D., A. \& Fuller, W., A. (1979). Distribution of the Estimators for Autoregressive Time Series with a Unit Root. Journal of the American Statistical Association, 74, 427-431.

Feder, G. (1982). On Exports and Economic Growth. Journal of Development Economics, 12, 59-73.

Helpman, E. \& Grossman, G. (1991). Innovation and Growth in the global economy. Cambridge: MIT press, chapters $1-5$.

Komijani, A. \& Memarnejad, A. (2004). Significant of Human Resource Quality an R\&D in Iran Economic Growth. Iranian Journal of Trade Studies, 8(32), 1-32.

Lucas, R., E. (1988). On the Mechanics of Economic Development. Journal of Monetary Economics, 22, 3342.

Pesaran, M., H., Shin, Y. \& Smith, R. (2001). Bounds testing approaches to the analysis of level relationships, J. Applied Econometrics 16, 289-326.

Raymo, J. (1995). Are investments in higher education productive: evidence from Japanese time series data. Osaka City University Economic Review, 30(1), 53-64.

Smith, A. (1776). An Inquiry Into the Nature and Causes of the Wealth of Nations, ed. R. H. Campbell and A. S. Skinner (Oxford: Oxford university Press, 1976 [orig. Pub. 1776]), Book IV. Hereafter Referred to as WN.

Wood, A. (1997). Exporting manufacture: Human resources, natural resources and trade policy. Journal of development studies, 34(1), 35-59. 